\title{
Population status of Spotted Deer in Baghmara Buffer Zone Community Forest, Chitwan National Park, Nepal
}

\author{
Shrijana Sapkota and Mukesh K Chalise \\ Central Department of Zoology, Tribhuvan University, Kirtipur, Kathmandu, Nepal
}

For correspondence: mukesh57@hotmail.com

\begin{abstract}
The population status of spotted deer was studied in Baghmara Buffer Zone Community Forest (BBZCF) during different four seasons of 2012-13. Population status was determined by direct count method at the time of its active movement in the morning and early evening. A total of 255 individuals of spotted deer were counted with a crude density of $118.6 \mathrm{deer} / \mathrm{km}^{2}$. Male to female sex ratio varied seasonally (summer-1: 2.2, rainy- 1: 2.22, autumn- 1: 2.15 and in winter- 1: 2.50). The average sex ratio of males to females was computed as 44.47:100. The largest herd of 41 individuals was observed in summer. The average herd size was 13.49. We used Kruskal-Wallis Rank Sum test to find the significant difference in mean population distribution due to seasons and blocks. There was no significant difference in mean population distribution due to seasons $(\chi 2=0.7624, \mathrm{df}=3, \mathrm{P}=0.8584)$ but significant differences was found in mean population distribution due to blocks $(\chi 2=52.7534, \mathrm{df}=13, \mathrm{P}=0.000000997)$.
\end{abstract}

Key words: BBZCF, direct count, herd, mean population, sex ratio

\section{Introduction}

The spotted deer or Chital (Axis axis) is one of the most beautiful deer of Nepal and a favourite object of sport because of its lovely spotted coat (Shrestha 2003). Spotted deer is classified as a member of order Artiodactyla under the family Cervidae (Mitchell 1982). Ellerman and Morrison-Scott (1964) recognize two sub species of Axis axis. Axis axis axis is native to Nepal, India and Srilanka and Axis axis ceylonensis is native to Srilanka.

The spotted deer is a medium sized deer standing about 35-38 inches at the shoulder and the coat is rufous brown with white spots (Schaller 1967). Spotted deer appears like a small elk or wapiti in outline. Does are slightly lighter in color than bucks especially over the face and neck (Graf and Nichols 1966). The average weight of males is $71 \mathrm{~kg}$ and the female is $50 \mathrm{~kg}$ in Chitwan National Park (CNP) (Mishra 1982). Only males have antlers and are functional during the mating season (Rajaram 2004).

Axis deer are found at lower elevations below $915 \mathrm{~m}$ (Ables 1977) and rarely found above an altitude of $1000 \mathrm{~m}$ in its native Asian habitat, including Nepal. They usually prefer ecotonal region between the forests and the grass patch (Mitra 1990). It is widely distributed cervids in the Indian sub-continent (Srinivasulu 2001). In Nepal, spotted deer occur throughout the Siwalik Hills and adjoining plains. Spotted deer preferred habitat is Tarai plain while may reach to the basin of inner mountains. They are found scattered in lower number in the mid-hill, warmer valleys and forest areas (Chalise 2001, 2013).

Nepalese Journal of Zoology | Online Volume 3 Issue 1 | November 2015 | Page 11 
It is distributed in Bardia National Park (BNP), CNP, Sukla-Phanta Wildlife Reserve (SWR), Parsa Wildlife Reserve (PWR) and Koshi Tappu Wildlife Reserve (Majupuria and Majupuria 2006). Spotted deer is considered as least concern as per the IUCN categories as it occurs over a very wide range with large populations (Chalise 2013, Duckworth et al. 2008).

\section{Materials and Methods}

This study was carried out in Baghmara Buffer Zone Community Forest, BBZCF (Location $27^{\circ} 34$.78'- $^{\prime}$ $27^{\circ} 35.53^{\prime}$ Northern Latitude and $84^{\circ} 28.43^{\prime}-84^{\circ} 29.40^{\prime}$ Eastern Longitude), Buffer Zone area of CNP, Chitwan, Nepal. The forest covers 215 ha area at 170 meter elevation (Sharma et al. 2011).

Population status was determined by direct count method assisted by binocular of 10x50 mm and age sex categorized. Hence to reduce biasness, total population was estimated by using statistical theorem. Observation was conducted concentrated mostly at the time of its active movement in the morning (6.009.00) and early evening (15.00-18.00). Counting was done in four seasons- Summer (April), Rainy (July), Autumn (November) of 2012 and winter (February) of 2013. The number of Spotted Deer was confirmed by repeated count in one observation session. During the total count, the exact total numbers were different at the same place in different replicates. The whole study area was divided into 14 micro habitats. The number of spotted deer was confirmed by repeated observation in one observation session. During the total count, the exact total numbers were different at the same place in different replicates. Hence to reduce biasness, estimated population was calculated by $\mathrm{N}=2 \mathrm{n}_{\mathrm{k}}-\mathrm{n}_{\mathrm{k}-1}$ formula and count was derived from first and second maximum counting such as:

Here, $\mathrm{N}=2 \mathrm{n}_{\mathrm{k}}-\mathrm{n}_{\mathrm{k}-1} \ldots \ldots \ldots \ldots \ldots \ldots \ldots \ldots \ldots$

Where,

$$
\begin{aligned}
& \mathrm{N}=\text { estimated population. } \\
& \mathrm{n}_{\mathrm{k}}=\text { highest Value of observed Population } \\
& \mathrm{n}_{\mathrm{k}-\mathrm{l}}=\text { second highest value of observed Population. }
\end{aligned}
$$

The approximate upper confidence limit $\left(\mathrm{N}_{\mathrm{u}}\right)$ at $100(1-\mathrm{a}) \%$ is obtained by;

$$
N_{u}=n_{k}+(1-a) / a\left(n_{k}-n_{k-1}\right) \ldots \ldots \ldots \ldots \ldots \ldots \ldots . .2
$$

Where,

$$
\begin{aligned}
& \mathrm{N}_{\mathrm{u}}=\text { upper confidence limit of population } \\
& \mathrm{a}=\text { the level of test }
\end{aligned}
$$

Similarly at given confidence limit the lower limit of population is given by

$$
\mathrm{N}_{\mathrm{L}=\mathrm{N}_{\mathrm{k}}}
$$

Hence, the range of total number $\mathrm{N}$ is given by

$$
\mathrm{N}_{\mathrm{L}}<\mathrm{N}<\mathrm{N}_{\mathrm{U}}
$$

\section{Data Analysis}

\section{For direct count method}

sR - Software (R Console Version 2.15.2) was used for the statistical analysis. It is a non parametric test and alternative to ANOVA. Since the data was not found normal, hence this test was performed. Kruskal-

Nepalese Journal of Zoology | Online Volume 3 Issue 1 | November 2015 | Page 12 
Wallis Rank Sum Test was used to find the significant difference in the mean population distribution of spotted deer in different habitat due to four seasons and in different seasons due to blocks.

\section{Results}

There were five different micro-habitats identified inside BBZCF. Habitat of Spotted deer was explored by using ecological quadrate method. Within each transect four quadrates of $25 \times 25 \mathrm{~m}^{2}$ for tree species, $5 \times 5 \mathrm{~m}^{2}$ for shrub species and $1 \times 1 \mathrm{~m}^{2}$ for herbs were made (Sharma et al. 2011). There were altogether 55 transects within 14 blocks. These micro-habitats were further divided into 14 blocks to make the study easier. Ten of the 14 blocks were used by deer frequently and taken for population counting (Table 1). The total number of spotted deer counted was 255 of different age and sex. Among 255 individuals of spotted deer, $137(53.73 \%)$ were females, $61(23.92 \%)$ were males and $57(22.35 \%)$ were young. The area of BBZCF is only of $2.15 \mathrm{~km}^{2}$. So the crude density is estimated to be $118.6 \mathrm{deer} / \mathrm{km}^{2}$.

Table 1. Population status of spotted deer in different blocks of BBZCF in 2012-13.

\begin{tabular}{|c|c|c|c|c|}
\hline \multirow[t]{2}{*}{ Habitat used } & \multirow[t]{2}{*}{ Blocks } & \multicolumn{2}{|c|}{ Population of spotted deer observed } & \multirow{2}{*}{$\begin{array}{l}\text { Estimated population } \\
\qquad N=2 n_{k}-n_{k-1}\end{array}$} \\
\hline & & $\operatorname{Maximum}\left(\mathrm{n}_{\mathrm{k}}\right)$ & $\begin{array}{c}\text { Second Maximum } \\
\left(\mathrm{n}_{\mathrm{k}-1}\right)\end{array}$ & \\
\hline \multirow{4}{*}{$\begin{array}{l}\text { Bhellar-Padke } \\
\text { (Trewia nudiflora } \\
\text { Albizia lucidior) } \\
\text { forest }\end{array}$} & A & 25 & 23 & 27 \\
\hline & G & 13 & 10 & 16 \\
\hline & $\mathrm{H}$ & 28 & 24 & 32 \\
\hline & $\mathrm{N}$ & 7 & 6 & 8 \\
\hline \multirow{3}{*}{$\begin{array}{l}\text { Bhellar forest } \\
\text { (Trewia nudiflora) }\end{array}$} & $\mathrm{E}$ & 27 & 26 & 28 \\
\hline & $\mathrm{L}$ & 38 & 36 & 40 \\
\hline & $\mathrm{M}$ & 8 & 6 & 10 \\
\hline $\begin{array}{l}\text { Padke (Albizia } \\
\text { lucidior) forest }\end{array}$ & $\mathrm{K}$ & 45 & 42 & 48 \\
\hline $\begin{array}{l}\text { Sisso (Dalbergia } \\
\text { sissoo) forest }\end{array}$ & B & 7 & 5 & 9 \\
\hline Grassland & $\mathrm{J}$ & 57 & 56 & 58 \\
\hline \multicolumn{2}{|c|}{ Total counted } & 255 & 234 & 276 \\
\hline
\end{tabular}

In Bhellar-Padke forest, at 95\% and 99\% confidence level, the upper limits are as highest as 104 and 424 respectively in block Hand the least as 26 and 106 respectively in block N (Table 2). At 90\% confidence level, the upper limit is highest as 72 in Padke forest (block K). Similarly, the lower limits are found to be highest as 57 in grassland (block J) and least as 7 in Sisso forest (block B) and Bhellar-Padke forest (block N).

The census in different seasons varied for the spotted deer in BBZCF. The total number of spotted deer counted was 237 in summer season. Out of them, 58 (24.47\%) were males, 129 (54.43\%) were females and $50(21.09 \%)$ were young. The male to female sex ratio was 1: 2.2 and the Young to female sex ratio was $1: 2.58$.

The total number of spotted deer counted was 203 in rainy season. Out of them, 49 (24.13\%) were males, $109(53.69 \%)$ were females and $45(22.16 \%)$ were young (Table 3). The male to female sex ratio was to be $1: 2.22$ and the young to female sex ratio was $1: 2.4$.

Nepalese Journal of Zoology| Online Volume 3 Issue 1 | November 2015 | Page 13 
The total number of spotted deer counted was 226 in Autumn season. Out of them, 54 (23.89\%) were males, $114(50.44 \%)$ were females and 58(25.66\%) were young. The male to female sex ratio was 1: 2.15 and the young to female sex ratio was computed to be $1: 1.96$.

Table 2. Range of population of spotted deer in different blocks in BBZCF in 2012-13

\begin{tabular}{|c|c|c|c|c|c|}
\hline \multirow[t]{3}{*}{ Habitat } & \multirow[t]{3}{*}{ Blocks } & \multirow[t]{3}{*}{$\mathrm{N}_{\mathrm{L}}=\mathrm{n}_{\mathrm{k}}$} & \multirow{2}{*}{\multicolumn{3}{|c|}{$\begin{array}{c}\text { Range of Estimated Population (N) } \\
\text { Levels of Test }\end{array}$}} \\
\hline & & & & & \\
\hline & & & $0.10(90 \%)$ & $0.05(95 \%)$ & $0.01(99 \%)$ \\
\hline \multirow{4}{*}{$\begin{array}{l}\text { Bhellar-Padke } \\
\text { (Trewia nudiflora } \\
\text { Albizia lucidior) } \\
\text { forest }\end{array}$} & $\mathrm{A}$ & 25 & $25<\mathrm{N}<43$ & $25<N<63$ & $25<\mathrm{N}<223$ \\
\hline & $\mathrm{G}$ & 13 & $13<\mathrm{N}<40$ & $13<\mathrm{N}<70$ & $13<\mathrm{N}<310$ \\
\hline & $\mathrm{H}$ & 28 & $28<N<64$ & $28<N<104$ & $28<\mathrm{N}<424$ \\
\hline & $\mathrm{N}$ & 7 & $7<N<16$ & $7<\mathrm{N}<26$ & $7<\mathrm{N}<106$ \\
\hline \multirow{3}{*}{$\begin{array}{l}\text { Bhellar forest } \\
\text { (Trewia nudiflora) }\end{array}$} & $\mathrm{E}$ & 27 & $27<N<36$ & $27<N<46$ & $27<N<126$ \\
\hline & $\mathrm{L}$ & 38 & $38<\mathrm{N}<56$ & $38<\mathrm{N}<76$ & $38<\mathrm{N}<236$ \\
\hline & $\mathrm{M}$ & 8 & $8<N<26$ & $8<N<46$ & $8<N<206$ \\
\hline $\begin{array}{l}\text { Padke (Albizia } \\
\text { lucidior) forest }\end{array}$ & $\mathrm{K}$ & 45 & $45<\mathrm{N}<72$ & $45<N<102$ & $45<\mathrm{N}<342$ \\
\hline Sisso forest & B & 7 & $7<\mathrm{N}<25$ & $7<\mathrm{N}<45$ & $7<\mathrm{N}<205$ \\
\hline Grassland & $\mathrm{J}$ & 57 & $57<\mathrm{N}<66$ & $57<\mathrm{N}<76$ & $57<\mathrm{N}<156$ \\
\hline
\end{tabular}

The total number of spotted deer counted was 232 in winter season. Out of them, 51(21.98\%) were males, $128(55.17 \%)$ were females, $53(22.84 \%)$ were young. The male to female sex ratio was $1: 2.50$ and the young to female sex ratio was $1: 2.41$.

Table 3. Number of spotted deer counted in different seasons in BBZCF

\begin{tabular}{|l|l|c|c|c|c|}
\hline S.N. & Seasons of year & Young & Males & Females & Total \\
\hline 1. & Summer & 50 & 58 & 129 & 237 \\
\hline 2. & Rainy & 45 & 49 & 109 & 203 \\
\hline 3. & Autumn & 58 & 54 & 114 & 226 \\
\hline 4. & Winter & 53 & 51 & 128 & 232 \\
\hline \multicolumn{2}{|l}{ Average Total in a year } & $\mathbf{5 1 . 5}$ & $\mathbf{5 3 . 0}$ & $\mathbf{1 2 0}$ & $\mathbf{2 2 4 . 5}$ \\
\hline
\end{tabular}

The average herd size was 13.49 individuals computed from 3,832 individuals in 284 herds during the study period. The largest herd size of 41 individuals (mixed herd) was observed in habitat J. There was no significant difference in mean population distribution due to seasons ( $\mathrm{P}$-value $>0.05$ ) but significant differences was found in mean population distribution due to habitat $(\mathrm{P}$-value $<0.05)$ (Table 4).

Table 4. Kruskal Wallis test of different seasons and habitat

\begin{tabular}{|c|l|l|l|l|}
\hline Variables & $\mathrm{X}^{2}-$ value & d.f & P-value & Remarks \\
\hline Seasons & 0.7624 & 3 & 0.8584 & No Significant \\
\hline Habitat & 52.7534 & 13 & 0.000000997 & Significant \\
\hline
\end{tabular}

Nepalese Journal of Zoology| Online Volume 3 Issue 1 | November 2015 | Page 14 


\section{Discussion}

Sharma et al. (2012) recorded a total of 182 individuals of spotted deer in BBZCF but we recorded 255 individuals of spotted deer in BBZCF. Seidensticker (1976) recorded 629 individuals of spotted deer in CNP with density of $17.7 \mathrm{deer} / \mathrm{km}^{2}$. This study computed crude density of $118.6 \mathrm{deer} / \mathrm{km}^{2}$. Raman et al. (1996) recorded density of 212.3 deer $/ \mathrm{km}^{2}$ in Guindy National Park, India. Spotted Deer prefers ecotonal region between the forests and the grass patch and avoid hilly terrain (Mitra 1990). Due to the availability of such type of habitat and resources in BBZCF, the difference in the study time, multiple observations, direct count method, small study area were possible reasons for higher population of spotted deer andhigh density estimate during this study.

Bedi (1985) counted about 600 spotted deer in a single herd in Corbett National Park, Kurt (1990) explained occurrence of 800 or more members of spotted deer in a herd in India and Srilanka. However, such large herds were not observed in this study area. Commonly, herds of 4 to 18 individuals were observed in this study and the largest herd of 41 individuals. The mean size of mixed herd was 13.49. Danger from the predators and the climatic factors could be the possible reasons behind their presence in small herds. The sex ratio of male to female was 0.59:1 in Sri Lanka (De Silva and De Silva 2001).Seidensticker (1976) found sex ratio as 115:100 in CNP. The average sex ratio of male to female was found to be 44.47:100 in BBZCF (seasonal basis). The sex ratio is found to be low in comparison to Sri Lanka and CNP. Illegal and selective hunting, unequal natality and mortality rates of male young etc may be the possible factors for the unequal sex ratio.

\section{Conclusion}

A total of 255 individuals of spotted deer were counted from different habitat and the crude density was computed to be $118.6 \mathrm{deer} / \mathrm{km}^{2}$. The highest population of spotted deer was counted in grassland (block J) and the lowest in sissoo dominated forest (block B). The average sex ratio was found to be 44.47 bucks to 100 does with more females than males in all the seasons. The highest sex ratio of 47.39 bucks to 100 does was found in Autumn season. The largest herd of 41 individuals was observed in grassland (block J) in summer. The average mixed herd size was computed as 13.49 individuals. Kruskal-Wallis test raveled that there was no significant difference $(\mathrm{P}>0.05)$ in the mean population distribution of deer in different habitat due to four seasons and there was a significant difference $(\mathrm{P}<0.05)$ in the mean population distribution of deer in different seasons due to different habitat.

\section{Acknowledgements}

We would like to thank Central Department of Zoology, TU, for approval of research, DNPWC and BBZCF for granting the permission to carry out this research work in Baghmara. We would like to express our sincere thanks to Mr Hari B Acharya, Mr Manoj Choudhary Mr Chandra Lama, and all the staff of BBZCF for their valuable information, continuous support, encouragements and suggestions during the research.

\section{References}

Ables, E.D. 1977. The Axis Deer in Texas.Texas A and M Agricultural Experimental station, Texas.

Bedi, R. 1985. Corbett National Park, Publisher Clarion books, Delhi, India, 188 p.

Chalise, M. K. 2001. Wildlife of Nepal (Part - 2).Nepal Natural History Society. Kathmandu, Nepal. Pp: 67. 
Chalise, M. K. 2013. Nepalka Mirgaharu (in Vernacular Nepali), Revoscience, Vol III, Nov-May, 19-20 p.

De silva, M. and de silva, P.K. 2001.Group composition, sex ratio and seasonality of spotted deer (Axis axis) in the Yala Protected Area Complex, Srilanka. Journal South Asian Natural History 5(2): 135-141.

Duckworth, J.W., Kumar, N.S., Islam, A. Md., Baral, H.S. and Timmins, R.J. 2008.Axis axis.In: IUCN 2012. IUCN Red List of Threartened Species.Version 2012.2. 〈www.iucnredlist.org>. Downloaded on 01 June 2013. Retrived on 05 June 2013.

Ellerman, J. and Morrison- Scott, T. 1966. Checklist of Palaearctic and Indian Mammals, $2^{\text {nd }}$ edition, Aldex, Oxford, $810 \mathrm{p}$.

Graf, W. and Nichols, L. 1966. The Axis Deer in Hawaii.Journal Bombay Natural History Society 63(3).

Kurt, F. 1990. Grzimek's Encyclopedia of mammals, Vol.5, McGraw- Hill Publishing Company, New York.

Majupuria, T.C. and Majupuria, R.K. 2006. Wildlife and Protected Areas of Nepal. Published by S. Devi, Sharanpur, India, $151 \mathrm{p}$.

Mishra, H.R. 1982. The Ecology and Behavior of Chital in the Chitwan National Park, Nepal.Ph.D Thesis, University of Eindurgh, U.K.

Mitchell, J. (Ed) 1982. The illustrated reference book of animals. W. H. Smith and Sons Ltd., England.

Mitra, T.R. 1990. Ecology of wild and captive chital (Axis axis, Erxleben), In: T.C. Majupuria(ed.): Wildlife wealth of India, Tecprss Service Bangkok, Thailand. P. 505-514.

Rajaram, A. 2004.Deer Antlers. Resonance p: 50-63.

Raman, T.R.S., Menon, R.K.G. and Sukumar, R. 1996. Ecology and Management of Spotted deer and Blackbuck in Guindy National Park, Madras. Journal Bombay Natural History Society 93: 178-192.

Schaller, G. B. 1967. The Deer and the Tiger. University of Chicago Press, Chicago, 37-89 p.

Seidensticker, J. 1976. Ungulate Populations in Chitwan Valley, Nepal. Biological Conservation 10: 183210.

Sharma, B.k., Chalise, M. K. and Solanki, G.S. 2011. Large wildlife Population in Baghmara Buffer Zone Community Forest, Nepal. Ecoprint 18: 55- 62, ISSN: 1024- 8668.

Shrestha, T. K. 2003. Wildlife of Nepal, $2^{\text {nd }}$ edition. Publisher BimalaShrestha.223-226 p.

Srinivasulu, C. 2001. Spotted deer (Axis axis, Erxleben, 1777) Herd Composition and Sex ratio on the Nallamala Hills of Eastern Ghats, Andhra Pradesh, India. Zoo's Print Journal 16(12): 655-658.

Nepalese Journal of Zoology | Online Volume 3 Issue 1 | November 2015 | Page 16 